\title{
HYSTEROSCOPIC MANAGEMENT OF INTRAUTERIN ADHESION
}

\author{
Fatih SENDAG, Aysegul DIKMEN, Levent AKMAN, Kemal OZTEKIN
}

Department of Obstetrics and Gynecology, Ege University, Faculty of Medicine, İzmir, Turkey

\section{SUMMARY}

Objective: Assessment of preoperative and postoperative outcomes of patients that were performed hysterescopic intrauterine adhesiolysis.

Material and method: We reviewed 24 patients that underwent hysterescopy with the complaints of amenorrhea, hypomenorrhea, recurrent pregnancy loss between 2004-2008. The most complaints of patients were infertilty amenorrhea. Results: Adhesions occurs mainly as a result of trauma to the gravid uterine cavity in 14 patients. When classifying patients with their intrauterine adhesions, Grade 3 was the most frequently seen. Adhesiolisis was performed with hysteresopic scissors in all patients. In postoperative period following synechiolysis, 10 patients were treated with estrogen and progestogen, 11 of them used intrauterine device with estrogen and progestogen therapy, foley catheter was used in 3 patients. Hysterescopy was performed in 5 patients for second time because of adhesion suspicions. The re-adhesiolysis performed to 3 patients because of determined to mild adhesion.

Conclusion: After hysterescopic adhesiolysis, all patients with the complaint of amenorrhea had regular menstruation. Pregnancy after treatment occured in 4 patients but live birth rate was $75 \%$

Key words: adhesiolisis, hysterescopy, infertility, uterin synechia

Journal of Turkish Society of Obstetrics and Gynecology, (J Turk Soc Obstet Gynecol), 2013; Vol: 10, Issue: 1, Pages: $21-5$

\section{INTRAUTERIN ADEZYONLARA HISTEROSKOPIK YAKLAŞIM}

\section{ÖZET}

Objektif: Kliniğimizde histeroskopik intrauterin adezyolizis uyguladı̆̆ımız hastaların demografik, klinik özellikleri ile beraber operasyon sonuçlarını sunmaktır.

Gereç ve yöntemler: 2004-2008 yılları arasında kliniğimizde 24 histeroskopik adezyolizis uygulanmıştır. Hastaların yaş grubu 25-39 yaş aralığında idi. En sık başvuru şikayetleri amenore ve infertilite idi.

Bulgular: Adezyon için risk faktörü olarak 10 hastada geçirilmiş gebelik küretajı ve 4 hastada geçirilmiş sezaryen operasyonu mevcuttu. İntrauterin adezyon sınıflandırıldı̆̆ında 5 hasta Grade I, 6 hasta Grade II, 10 hasta Grade III ve 3 hasta Grade IV olarak tespit edildi. Tüm hastalarda histeroskopik makas kullanılarak adezyolizis yapılmıştır. Postoperatif dönemde 10 hastaya estrojen-progesteron içerikli ilaç, 11 hastaya hormon ile beraber rahim içi araç ile 3 hastaya foley katater balon uygulanmıştır. Hastaların izleminde tekrar adezyondan şüphelenilen 5 hastaya tekrar histeroskopi yapılmıştır. Hafif adezyon saptanan 3 hastada adezyonlar tekrar giderilmiştir.

Sonuç: Tüm amenoreik hastalarda menstrüel periyot geri dönmüştür. Yardımcı üreme tedavisi uygulanmış 4 hastaya ulaşılabilmiştir. Dört gebelik elde edilmiş ve üçü terme ulaşmış, bir tanesi de abortus ile sonuçlanmıştır.

Anahtar kelimeler: adezyolizis, histeroskopi, infertilite, uterin sineși

Türk Jinekoloji ve Obstetrik Derneği Dergisi, (J Turk Soc Obstet Gynecol), 2013; Cilt: 10, Sayl: 1, Sayfa: 21- 5

Address for Correspondence: Dr. Levent Akman. Ege Üniversitesi Tıp Fakültesi, Kadın Hastalıkları ve Doğum Anabilim Dalı, 35100 İzmir Tel: + 90 (532) 4623009

e-mail: leventakman@gmail.com

Received: 20 May 2012, revised: 18 July 2012, accepted: 28 August 2012, online publication: 29 August 2012 


\section{INTRODUCTION}

Intrauterine adhesions may occur after intrauterine trauma. The severity of the adhesions vary: some are focal and small bands, some extensive, some even total occlusion of the uterine cavity. Uterine surgery and diagnostic curretage are common reasons of adhesions but serious adhesions usually arise from pregnancy complications such as postpartum hemorrhage, missed or complet abortus and placenta retention ${ }^{(1)}$. Multiple curretages performed for pregnancy termination is also a risk factor and adhesion risk is more than $30 \%$ after the third curretage ${ }^{(2)}$. Infections, especially uterine tuberculosis causing severe adhesions, have an important role on adhesion formation ${ }^{(3)}$.

Intrauterine adhesions may be asymptomatic but generally are related with infertility, menstrual disroders (hypomenorrhea, amenorrhea), cyclic pelvic pain and recurrent abortus ${ }^{(1)}$. Indirect imaging methods give useful information in diagnose but the gold standard diagnostic method is hysteroscopy which has the adventage of concurrent treatment.

The aim of this study is to evaluate the clinical characteristics of the patients who underwent hysteroscopic adhesiolysis and fertility outcomes in infertile patients.

\section{MATERIAL AND METHODS}

Twenty four patients who diagnosed with intrauterine adhesions between 2004-2008 were included in the study. All the patients had hypomenorrhea or amenorrhea and 14 patients were infertile. Patients were preoperatively evaluated by ultrasonography, hysterosalpingography and progesterone withdrawal test. Adhesions were classified by hysteroscopy with abdominal ultrasonography according to European Society of Hysteroscopy (ESH) staging (Table I) ${ }^{(4)}$.

In all patients hysteroscopic adhesiolysis was performed under general anesthesia by the same surgeon (F.S.). The goal of hysteroscopic lysis of adhesions is to restore the normal anatomy of the uterus. Procedures were performed in early follicular phase. After cervical dilatation, uterine cavity was explored with a $5.5 \mathrm{~mm}$ rigid hysteroscope (Karl Storz, Germany). Saline was used as distension solution. Adhesions were removed with sharp scissors under the guidance of abdominal ultrasonography. Dissection was carried on until the pink myometrial tissue of fundus was seen and both tubal ostia were sighted. Fluid balance was held in check during procedure. Operation was finished after hemostasis. Mean operation time is 20 minutes. All the patients were given oral hormonal therapy ( $2 \mathrm{mg}$ estradiol valerate for 21 days and additional $0.5 \mathrm{mg}$ norgestrel on last 10 days) for 1-3 months after hysteroscopy for preventing recurrent adhesions. Additionally Tshaped intrauterine device was inserted to 11 patients and foley catheter balloon was administered for 7-10 days to other 3 patients. All the patients were discharged from hospital on the same day. Patients were performed a control hysteroscopy in case of lack of menstruation with cyclic hormonal therapy and if exists, adhesions were removed by the same method as before. Third hysteroscopy was not needed in any of the patients.

Table I: European Society for Hysteroscopy classification of intrauterine adhesions.

1. Thin or filmy adhesions easily ruptured by hysteroscope sheath alone. Cornual areas normal.

2. Singular filmy adhesions connecting separate parts of the uterine cavity. Visualization of both tubal ostea possible. Cannot be ruptured by hysteroscope sheath.

2a: Occluding adhesions only in the region of the internal cervical os. Upper uterine cavity normal.

3. Multiple firm adhesions connecting separate parts of the uterine cavity. Unilateral obliteration of ostial areas of the tubes. 3a: Extensive scarring of the uterine cavity wall with amenorrhea or hypomenorrhea.

3b. Combination of III and IIIa.

4. Extensive firm adhesions with agglutination of uterine walls. Both tubal ostial areas occluded.

\section{RESULTS}

Between 2004-2008, hysteroscopic adhesiolysis was performed to 24 patients. Menstrual disorder and infertility was complaining of the patients and were diagnosed intrauterine adhesion. Mean age of the patients were 25-39. Eight (30\%) patients had amenorrhea and $16(70 \%)$ patients had hypomenorrhea. Infertility was detected in 14 patients.

The predispositon factors were pregnancy termination in $10(42 \%)$ patients and caesarean section in $4(16 \%)$ patients. Other patients had no risk factors. 
Adhesions were classified as Grade 1 in 5 patients, Grade 2 in 6 patients, Grade 3 in 10 patients and Grade 4 in 3 patients. All adhesiolysis procedures were performed by hysteroscopic scissors. Control hysteroscopy was needed in two Grade 4 and three Grade 3 patients. Control hysteroscopies revealed Grade 1 adhesions in 3 of 5 patients and adhesiolysis was performed. Other 2 patients had menstruation after cyclic hormonotherapy.

Normal menstruation was achieved in all patients and there were no perioperative complications. We could reach 4 of 14 infertile patients in long-term follow up and pregnancy was provided with assisted reproductive techniques in these 4 patients. One patient had spontaneous abortus in six gestational weeks and other 3 patients had term delivery; 1 spontaneous vaginal and 2 caesarean sections due to obstetric factors. The babies are healthy.

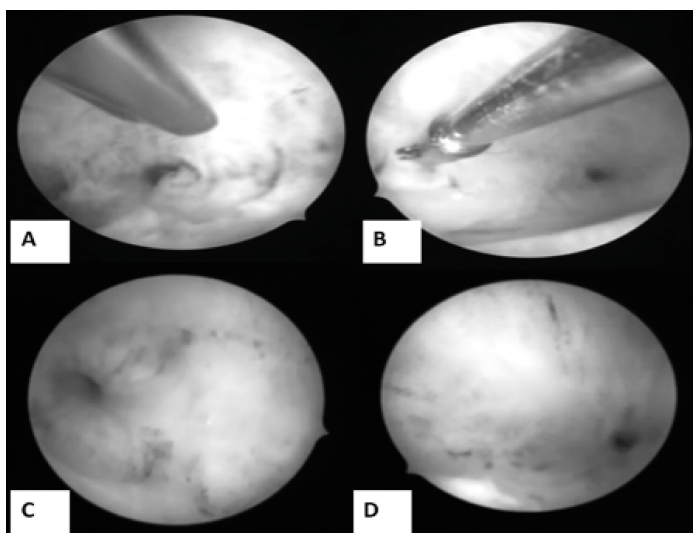

Figure 1A: Surgical removal of adhesion with use to sharp scissors. B: In hysterescopic view, removal of adhesion in right tubal ostium as seen obliterated and left tubal ostium is seen clearly. C: In control hysteroscopy, the adhesions were removed, and right and left tubal ostiums were seen clearly (D).

\section{DISCUSSION}

Intrauterine adhesion has been a well known disorder since early 1900s but it is firstly described by Joseph Asherman in $1948^{(5)}$. Pathologic examinations reveal fibrous connective bands with or without glandular tissue. Incidence of intrauterine adhesions has been increased in recent years ${ }^{(2)}$. Elective pregnancy terminations usually carry low risk. Prevalence and severity of adhesions are closely related with multiple intrauterine procedures. Basal layer of endometrium is sensitive to injury during the first four weeks after delivery or abortus. Therefore, should be avoided to curratage in this period ${ }^{(5)}$. Intrauterine adhesion to keep in mind, if the unsuccessfull procedure with hystereometer and negative progesteron withdrawal test were seen in these patient.

Hysteroscopy with its adventages of less uterine trauma and concurrent treatment facility, is the gold standard diagnostic method.

The suspicious is essential for diagnosis of intrauterin adhesion. Transvajinal ultrasonografi (TVUSG), HSG and salin infusion sonohysterography are also helpfull. A study with 65 infertil patients, due to compare those three metods with hysteroscopy shows that HSG and sonohysterography are equal sensivity to diagnose intrauterine adhesion ${ }^{(6)}$. TVUSG is less effective to diagnose for intrauterine adhesion.

There is no randomized controlled trial concerning the treatment of intrauterin adhesions. Standard treatment is remove the adhesion with under observation. The aim of procedure is to reach normal anatomy of uterine cavity and a functional endometrium. Operative hysteroscopy is prefered in the treatment. Adhesions may remove with pressure of salin infusion. Apply sharp scissors, electrosurgery and laser apparatus may necessary.

Cervical dilatation should be gentle in patient with severe adhesions. Uterine perforation or diffucult insert in to uterine cavity, may occur due to wrong way create during cervical dilatation. If the anatomy can not recognize well, transabdominal USG or laparoscopy apply are usefull. We perform all procedures with transabdominal USG and sharp scissors. Rarely complication may occur performing hysteroscopic adezyolysis. Uterine perforation, salin overload, electrolyte imbalance, hemorrhage, and infection is early complication. Longterm complications are recurrent adhesions and uterine perforation in pregnancy.

Uterine adhesions occur after incomplete abortion (50\%), postpartum hemorrhage (24\%) and elective termination of pregnancy $(17 \%)(7)$. It has been reported as underlying factor myomectomy, hysterectomy, diagnostic curettage, cesarean section, tuberculosis and uterine compression sutures with the packaging. $(1,8)$. In our series, there was a $42 \%(10 / 24)$ previous pregnancy curettage and $16 \%(4 / 24)$ previous caesarean 
section operation. A study evaluate adhesions after the termination of pregnancy with hysteroscopy at 3 . and 12. months $(9)$. They found that $\% 37$ of patients had varying degrees of adhesions.

Hormonal therapy, intrauterine device or balloon catheters are usefull to prevent postoperative new adhesions. There is no study, efficacy of these compare with untreated patients. Estrogen and progestin treatment after the procedure prevent adhesions although it has not supported by evidence. A study compare postoperative intrauterine device and balloon catheter $^{(8)}$. Cyclic menstruation of balloon catheter group was found $81 \%$ and the intrauterine device group was found $63 \%$. In our series, hormonal treatment selected in mild adhesions, intrauterine device or balloon catheter in addition to hormonal treatment selected intense adhesions. After the treatment, reproductive results and the returning of menstrual problems indicate that there is a correlation with the severity of adhesions and the intensity of adhesions. (11-14). The normal thickness of the endometrium may never come back again after the treatment. This also negatively affects to the pregnancy results. Minimal adhesions has a better prognosis on pregnancy rates and term pregnancy(3), severe adhesions has low pregnancy results. 187 patients were treated with hysteroscopic series, 143 pregnancies were obtained, $79 \%$ of them $(114 / 143)$ were reached the term, $18 \%(26 / 143)$ were terminated in spontaneous abortion and 2\% (3/143) were developed an ectopic pregnancy. Evaluate the severity of adhesions, the rate of pregnancy in moderate adhesions was found $81.3 \%$, the rate of pregnancy in severe adhesions was found $31.9 \%{ }^{(7)}$. In our series, cyclic menstruation provided in all patients. $75 \%$ $(3 / 4)$ of pregnancies had achieved term, 1 patient $(25 \%)$ was resulted in spontaneous abortion. Pregnancy, may resulted spontaneous abortion, preterm delivery, fetal presentation, placental abnormalities and anomalies in these patient with previous underwent adhesiolysis. Because of these reasons, pregnant women are follow-up closely.

As a result, the hysteroscopic examination has a low rate complication and reliably in the diagnosis and treatment of intrauterine adhesions. And it is succesfull to show the location and extent of the disease.

\section{REFERENCES}

1. Schenker JG. Etiology of and therapeutic approach to synechia uteri, Eur J Obstet Gynecol Reprod Biol. 1996; 65: 10911.

2. Letterie, GS. Structural abnormalities and reproductive failure: effective techniques for diagnosis and management, Blackwell Science, Massachusetts 1998.

3. Netter A, Musset R, Lambert A, Salomon Y, Montbazet G. Tuberculous endo-uterine symphysis; an anatomo-clinical and radiologically characteristic syndrome. Gynecol Obstet. 1955; 54: 19

4. Valle RF, Sciarra JJ. Intrauterine adhesions: hysteroscopic diagnosis, classification treatment and reproductive outcome. Am J Obstet Gynecol 1988; 158: 1459- 70.

5. Berman JM. Intrauterine adhesions Semin Reprod Med. 2008; 26: 349- 55 .

6. Soares SR, Barbosa dos Reis MM, Camargos AF. Diagnostic accuracy of sonohysterography, transvaginal sonography, and hysterosalpingography in patients with uterine cavity diseases. Fertil Steril. 2000; 73(2): 406.

7. Salzani A, Yela DA, Gabiatti JR, Bedone AJ, Monteiro IM. Prevalence of uterine synechia after abortion evacuation curettage Sao Paulo Med J. 2007;125: 261- 4.

8. Luk J, Allen RH, Schantz-Dunn J, Goldberg AB. Intrauterine adhesions as a risk factor for failed first-trimester pregnancy termination Contraception. 2007; 76: 331- 3.

9. Colacurci N, Fortunato N, Nasto R, Mele D, Errico G, De Franciscis $\mathrm{P}$, Zarcone R, Reproductive outcome of hysteroscopic lysis of intrauterine adhesions, Minerva Ginecol. 1997; 49: 3257.

10. Goldenberg M, Sivan E, Sharabi Z, Mashiach S, Lipitz S, Seidman DS Reproductive outcome following hysteroscopic management of intrauterine septum and adhesions, Hum Reprod. 1995; 10: 2663- 5.

11. Pabuccu R, Onalan G, Kaya C, Selam B, Ceyhan T, Ornek $\mathrm{T}$, et al. Efficiency and pregnancy outcome of serial intrauterine device-guided hysteroscopic adhesiolysis of intrauterine synechiae, Fertil Steril. 2008; 90: 1973- 7.

12. Zikopoulos KA, Kolibianakis EM, Platteau P, de Munck L, Tournaye H, Devroey P,et al. Live delivery rates in subfertile women with Asherman's syndrome after hysteroscopic adhesiolysis using the resectoscope or the Versapoint system. Reprod Biomed Online 2004; 8: 720 - 5.

13. Capella-Allouc S, Morsad F, Rongières-Bertrand C, Taylor S, Fernandez H. Hysteroscopic treatment of severe Asherman's syndrome and subsequent fertility. Hum Reprod 1999; 14: 
1230- 3 .

14. Katz Z, Ben-Arie A, Lurie S, Manor M, Insler V. Reproductive outcome following hysteroscopic adhesiolysis in Asherman's syndrome. Int J Fertil Menopausal Stud 1996; 41: 